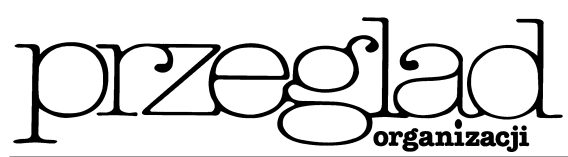

\title{
Kategoryzacja wiedzy \\ w organizacji zarządzanej procesowo
}

https://doi.org/10.33141/po.2005.78.08

Przegląd Organizacji, Nr 7/8 (786/787), 2005, ss. 33-35

www.przegladorganizacji.pl

Towarzystwo Naukowe Organizacji i Kierownictwa (TNOiK)

\section{$\overline{\text { Andrzej Chodyński, Adam Stefan Jabłoński, Marek Marian Jabłoński }}$}

\section{Rola wiedzy w organizacji działającej na konkurencyjnym rynku}

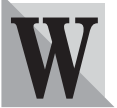

ramach dynamicznych zmian rynkowych oraz rozwoju nowoczesnych koncepcji zarządzania, wiedzę traktuje się jako szczególny, strategiczny zasób, który poprzez właściwe wykorzystanie może przyczynić się, a nawet znacząco wpłynąć na pozycje konkurencyjne przedsiębiorstw. Na różne źródła przewagi strategicznej wskazują zmieniające się $\mathrm{z}$ upływem lat szkoły myślenia strategicznego. Wiele opracowań określa różne czynniki kształtujące pozycję konkurencyjną firmy, sam zaś proces wzrostu konkurencyjności firmy oparty być może na identyfikacji i budowie przewagi konkurencyjnej, tworzeniu podstaw konkurencyjności z wykorzystaniem potencjału konkurencyjności i umiejętności wykorzystania odpowiednich instrumentów konkurowania z uwzględnieniem wpływu otoczenia na pozycję konkurencyjną firmy. Wskazuje się przy tym na rolę wiedzy w osiaganiu tej pozycji ${ }^{1}$. Cechą współczesnych organizacji są produkty i procesy bogate $\mathrm{w}$ wiedzę, a orientacja procesowa dominuje w funkcjonowaniu firm.

Szansa na uzyskanie wysokiej pozycji konkurencyjnej tkwi w kapitale intelektualnym organizacji. Formą jego uaktywnienia jest umiejętne zarządzanie wiedza, które musi oczywiście uwzględniać jej miejsce w realizowanych i projektowanych procesach w organizacji.

W niniejszej publikacji przyjęto najczęściej występujący podział procesów gospodarczych, biznesowych na procesy zasadnicze, zarządzające i wspomagające. Procesy zasadnicze o charakterze operacyjnym odnosza się do rozpoznania rynku, produkcji i dystrybucji, świadczenia usług, projektowania, marketingu i sprzedaży.

Procesy zarządzające (zarządcze) i wspierające (wspomagające) obejmują zarządzanie zasobami ludzkimi, finansowymi, rzeczowymi, informacja, relacjami organizacji z otoczeniem, poprawę efektywności oraz zarządzanie programami ochrony środowiska (te ostatnie najczęściej jako procesy wspomagające), ale też opracowanie wizji i strategii organizacji.

Mając na uwadze ekologizację procesów biznesowych, np. w przypadku firm realizujacych założenia zrównoważonego rozwoju, wyodrębnić można oddzielne procesy zarządzające związane z ekologią (np. procesy identyfikacji aspektów środowiskowych, proces monitorowania i pomiarów aspektów środowiskowych, proces zarządzania programami środowiskowymi). Istotna jest przy tym odpowiedź na pytanie, $w$ jaki sposób poszczególne kategorie wiedzy wpływają na realizację procesów.

Cechą wiedzy jest fakt, że opisuje ona zdolności i możliwości odnoszące się do nowych kontekstów działania. Wiedza zatem to zdolność do rozwiązywania danego zbioru problemów z daną efektywnością ${ }^{2}$. Wykorzystuje przy tym informacje i dane.

W niniejszym artykule spróbowano zdefiniować model praktycznego zarządzania wiedzą dla organizacji zarządzanej procesowo. Definiując rodzaje kategorii wiedzy w procesach zwrócono uwagę na aspekty pozyskiwania nowej wiedzy, jej upowszechniania i wykorzystania w produktach lub usługach organizacji.

Model praktycznego zarządzania wiedzą musi uwzględniać fakt, że dla jej praktycznego wykorzystania niezbędne jest stworzenie systemu wiedzy i możliwości korzystania z baz wiedzy. Tworzenie baz wiedzy jest więc metoda organizacji zasobów wiedzy. Wykorzystanie baz wiedzy powinno być rozpatrywane także w ujęciu procesów zachodzących w organizacji.

W literaturze wymienia się najczéściej trzy modele organizacji wiedzy: według procesów, według funkcji i według zagadnień (model koncepcyjny). Jako najczęstsze metody reprezentacji i organizacji wiedzy wykorzystywane są infomapy ${ }^{3}$.

\section{Podejście procesowe a zarządzanie wiedzą}

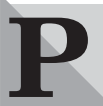

odstawowym założeniem jest, że procesy i ich wzajemne sekwencje powinny przyczyniać się do tworzenia wartości dodanej dla klienta oraz samej organizacji.

Przedsiębiorstwo poziomo zorganizowane według procesów charakteryzuje się tym, że:

- stanowi zbiór procesów operacyjnych i projektów wspomaganych przez inne procesy i funkcje pomocnicze, wnoszące wkład do wytworzenia wartości dla klienta;

- umożliwia poprawianie i reengineering procesów pod kątem jakości, kosztów i terminów oraz rozwój ludzi;

- występuje koordynacja wzdłuż procesów, kierowanie przez relacje klient - dostawca, a szef zmienia się w szkoleniowca (coach);

- dominuje komunikacja pozioma;

- występuje koncentracja na zarządzaniu procesami i rezultatach procesów;

- zasoby ludzkie rozdzielone są między procesy oraz podprocesy lub projekty;

- istnieje koncepcja klientów zewnętrznych i wewnętrznych;

- powoływane są zespoły wielodyscyplinarne;

- procesy są uproszczone, ale zadania bardziej kompleksowe ${ }^{3}$.

W ujęciu tym wiedza nie jest wyraźnie eksponowana, a przecież wiedzę, z jednej strony można wykorzystać przy projektowaniu procesów, a z drugiej doświadczenia z realizacji procesów są źródłem nowej wiedzy w organizacji. 
Tab. Zestaw kategorii wiedzy dla organizacji

\begin{tabular}{|c|c|c|c|c|}
\hline \multirow{2}{*}{ Lp. } & \multicolumn{3}{|c|}{ Kategoria wiedzy } & \multirow{2}{*}{$\begin{array}{c}\text { Symbol } \\
\text { kategorii wiedzy }\end{array}$} \\
\hline & Główne kategorie & \multicolumn{2}{|c|}{ Podkategorie } & \\
\hline & \multirow{3}{*}{ Klienci } & \multicolumn{2}{|l|}{ Współpraca } & KW \\
\hline & & \multicolumn{2}{|l|}{ Wymagania i potrzeby } & $\mathrm{KP}$ \\
\hline & & \multicolumn{2}{|l|}{ Wyniki oraz zadowolenie } & $\mathrm{KZ}$ \\
\hline & \multirow{3}{*}{ Dostawcy } & \multicolumn{2}{|l|}{ Współpraca bieżąca } & DW \\
\hline & & \multicolumn{2}{|l|}{ Kryteria współpracy } & DK \\
\hline & & \multicolumn{2}{|l|}{ Oceny rynkowe } & DO \\
\hline & \multirow{3}{*}{ Pośrednicy } & \multicolumn{2}{|l|}{ Współpraca bieżąca } & PW \\
\hline & & \multicolumn{2}{|l|}{ Kryteria współpracy } & PK \\
\hline & & \multicolumn{2}{|l|}{ Oceny rynkowe } & $\mathrm{PO}$ \\
\hline & \multirow{3}{*}{ Współpracujące instytucje } & \multicolumn{2}{|l|}{ Kryteria współpracy } & WK \\
\hline & & \multicolumn{2}{|l|}{ Zdarzenia istotne } & WZ \\
\hline & & \multicolumn{2}{|l|}{ Oceny rynkowe } & WO \\
\hline & Potencjalni pracownicy & \multicolumn{2}{|l|}{ Baza wiedzy o kandydatach } & $\mathrm{PB}$ \\
\hline & \multirow{4}{*}{ Pracownicy } & \multicolumn{2}{|c|}{ Baza wiedzy o pracownikach (kadry) } & $\mathrm{PO}$ \\
\hline & & \multicolumn{2}{|c|}{\begin{tabular}{|l|} 
Eksperci wewnętrzni \\
\end{tabular}} & $\mathrm{PE}$ \\
\hline & & \multicolumn{2}{|l|}{ Szkolenia i dokształcanie } & PS \\
\hline & & \multicolumn{2}{|l|}{ Wyniki i osiągnięcia } & $\mathrm{PO}$ \\
\hline & & \multicolumn{2}{|l|}{ Niezgodności } & $\mathrm{ZN}$ \\
\hline & & Audyty wewnętrzne & & $\mathrm{ZA}$ \\
\hline & Jakość wyrobów/usług & Działania korygujące & & ZK \\
\hline & i procesów, zarządzanie & Działania zapobiegawcze & & $\mathrm{ZZ}$ \\
\hline & środowiskowe, zarządzanie & Analizy danych & & ZD \\
\hline & BHP (zintegrowany system & Zmiany w systemach zarządzar & kumentacja) & $\mathrm{ZS}$ \\
\hline & zarządzania) & Informacje odnoszące się do wy & usług & $\mathrm{ZW}$ \\
\hline & & Aspekty środowiskowe (rodzaje & vyniki monitorowania) & $\mathrm{ZS}$ \\
\hline & & Zagrożenia BHP (rodzaje i wyn & nitorowania) & $\mathrm{ZZ}$ \\
\hline & & Informacje ogólne & & JO \\
\hline & Infrastruktura & Wyniki oceny, przeglądów, nap & & JP \\
\hline & & Rachunkowość finansowa & & FU \\
\hline & Finanse & Rachunkowość zarządcza & & FZ \\
\hline & & Nowe worroby/usłuoi procecy & Wdrożenie & JNW \\
\hline & Innowacyjność & Nowe wyroby/ustugi, procesy & Pomysły & JNP \\
\hline & produktów/usług i procesów & Zmiany w wyrobach/usługach, & Wdrożenie & JZW \\
\hline & & $\begin{array}{l}\text { procesach } \\
\end{array}$ & Pomysły & JZP \\
\hline & Strateoie i driałania & Krótkookresowe & & SK \\
\hline & Nitavegic i uatarantia & Długookresowe & & SD \\
\hline & Reolizacia wryrobów/ucłur. & Planowanie & & $\mathrm{RP}$ \\
\hline & hedilzalja wyronow/using & Wyniki działania & & RW \\
\hline
\end{tabular}

Źródło: opracowanie własne.

W ramach budowania systemów monitorowania skuteczności i efektywności procesów organizacja może wypracować model wykorzystania wiedzy. Niezbędne jednak jest, aby organizacja wiedziała, jaka wiedzą dysponuje i gdzie się ona znajduje. Istotne jest, by móc łatwo do wiedzy dotrzeć i by organizacja umiała zarządzać przepływem informacji oraz wiedzy. Podejście procesowe szczególnie zwraca uwage właśnie na obieg informacji oraz wiedzy w celu efektywnego tworzenia wartości.

Pozostaje jednak pytanie, jakie rodzaje wiedzy $\mathrm{w}$ organizacjach powinny być definiowane. Wydaje się słuszne stwierdzenie, że nie da się określić skończonej liczby kategorii wiedzy; jest ona zależna zarówno od rodzaju branży, czy sektora, w którym ta organiza- cja działa, jak i realizowanych procesów, czy stosowanych systemów zarządzania.

W przypadku gdy organizacja posiada sformalizowane systemy zarządzania generatorem wiedzy mogą być zapisy wymagane do funkcjonowania tych systemów (np. zarządzanie jakością czy zarządzanie środowiskowe).

W ramach podejścia procesowego niezbędne jest w organizacjach zdefiniowanie i sprecyzowanie wzajemnych zależności pomiędzy procesami. Po opracowaniu tzw. krajobrazu procesów możliwe jest zdiagnozowanie rodzajów wiedzy, które dzięki realizacji tych procesów są pozyskiwane. Równocześnie określić można kategorie wiedzy wspomagajace tworzenie tych procesów. W tabeli przedstawiono próbę skategoryzowa- 
PROCESY ZARZĄDZAJĄCE

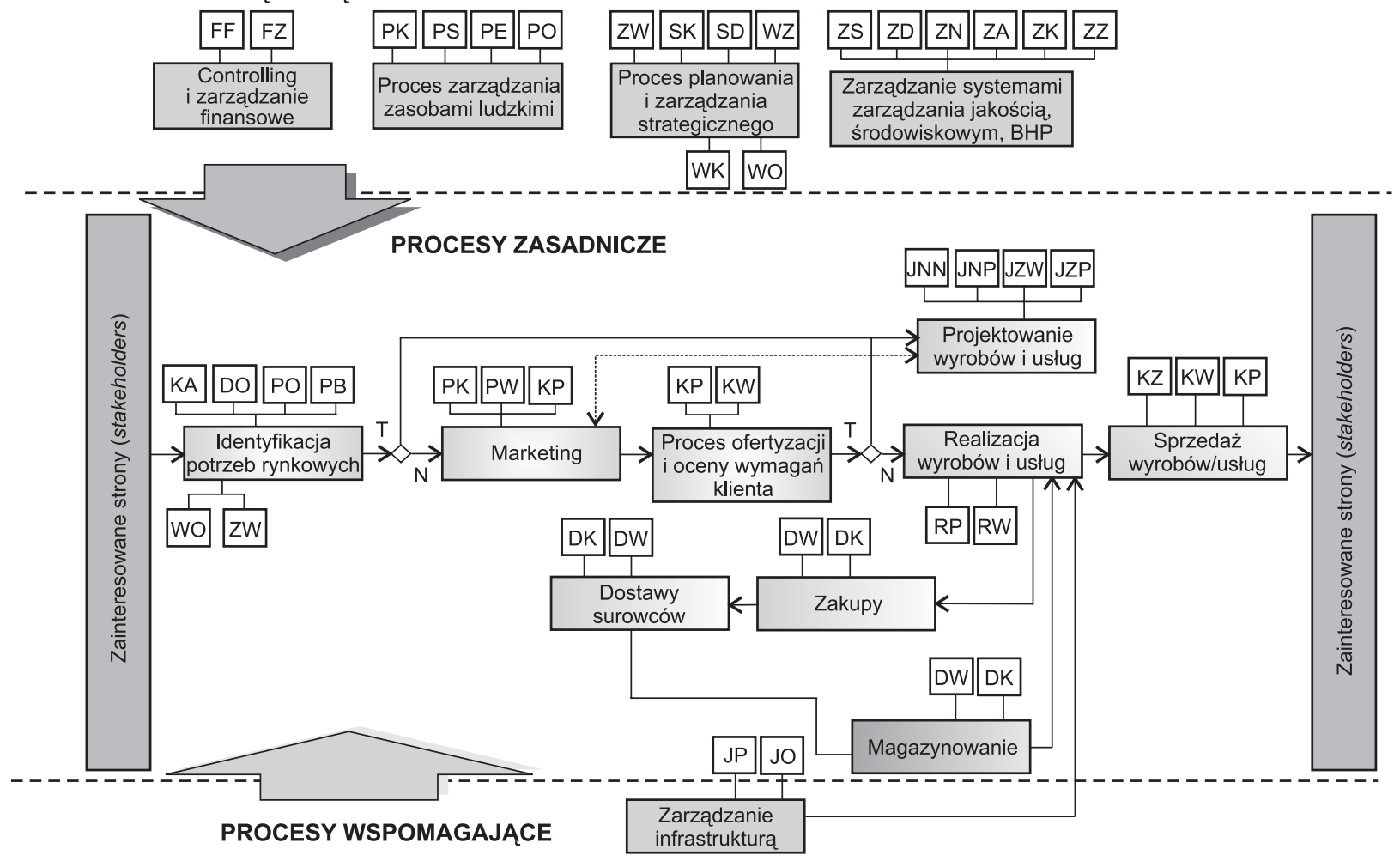

Rys. Krajobraz procesów z przyporządkowaniem własnych kategorii wiedzy określonych w tabeli

Źródło: opracowanie własne.

nia wiedzy w poszczególnych strategicznych obszarach działalności firmy z nadaniem im symboli właściwych kategorii wiedzy. Wymienione w tabeli rodzaje wiedzy odnoszą się do organizacji, która wdrożyła i stosuje zintegrowany system zarządzania jakościa, środowiskiem oraz BHP według norm ISO 9001:2000, ISO 14001 oraz PN-N 18001.

Realizacja prezentowanych systemów stanowi punkt wyjścia do totalnego zarzadzania jakościa według koncepcji TQM. Przyjmuje się, że realizacja tej koncepcji opierać się powinna na kapitale intelektualnym organizacji.

Systemy te w swej strukturze obejmują problematykę klienta (rynku), działań innowacyjnych w obszarze produktów (i procesów) oraz doskonalenie jakości, poprawę środowiska naturalnego i warunków pracy. Innowacyjność i jakość będaca w centrum zainteresowań tych systemów sa wyraźnie wskazywane jako źródła przewagi konkurencyjnej firm i znajdują swoje odbicie także w modelach kapitału intelektualnego ${ }^{4)}$ Odbicie w tych modelach znajduja też podkategorie wiedzy objęte systemowymi działaniami w firmie, a odnoszące się do klientów, dostawców, pracowników i infrastruktury.

Po przeprowadzeniu kategoryzacji wiedzy (poszczególnych jej rodzajów) przyporządkowano je zdiagnozowanym uprzednio procesom organizacji z podziałem na procesy zarządzające, zasadnicze i wspomagające (rysunek)

\section{Podsumowanie}

artykule dokonano próby kategoryzacji rodzajów wiedzy pozyskiwanej dzięki projektowaniu i realizacji procesów w firmie.
Zwrócono uwage na fakt, że zarządzanie wiedza opiera się na potencjale intelektualnym organizacji i stanowi formę jego wykorzystania m.in. poprzez realizację procesów. Do celów aplikacyjnych dokonano kategoryzacji wiedzy.

Kategoryzacja wiedzy wraz z przyporządkowaniem jej rodzajów do poszczególnych procesów umożliwić może praktyczne zarządzanie wiedzą $\mathrm{w}$ organizacji. Umiejętność praktycznego zarządzania wiedza stanowi zaś przesłankę do uzyskania pożądanej pozycji konkurencyjnej firmy.

prof. WSZiM dr hab. Andrzej Chodyński dyrektor Instytutu Zarządzania i Marketingu Wyższej Szkoły Zarządzania i Marketingu w Sosnowcu profesor Krakowskiej Szkoły Wyższej im. Andrzeja Frycza-Modrzewskiego mgr inz. Adam Stefan Jabtoński

Wyższa Szkoła Zarządzania i Marketingu w Sosnowcu,

mgr inz. Marek Marian Jabłoński

Wyższa Szkoła Zarządzania i Marketingu w Sosnowcu

\section{PRZYPISY}

1) Konkurencyjność przedsiębiorstw - nowe podejście, red. nauk. E. SKAWIŃSKA, Wyd. Nauk. PWN, Warszawa 2002.

2) A. ZALIWSKI, Korporacyjne bazy wiedzy, PWE, Warszawa 2000.

3) J. BRILMAN, Nowoczesne koncepcje i metody zarzadzania, PWE, Warszawa 2002.

4) Zarzadzanie organizacjami z perspektywy gospodarki opartej na wiedzy, praca zbiorowa pod red. A. CHODYNSKIEGO, WSZiM, Sosnowiec 2003. 